\title{
The influence of substratum type and nutrient supply on biofilm organic matter utilization in streams
}

\author{
Anna M. Romaní \\ Institut d'Ecologia Aquàtica, Departament Ciències Ambientals, Universitat de Girona, Campus de Montilivi 17071- \\ Girona, Spain \\ Adonis Giorgi \\ PIEA, Departamento Ciencias Básicas, Universidad Nacional de Luján. C. C 221-6700-Luján, Argentina
}

\section{Vicenç Acuña}

Departament d'Ecologia, Facultat Biologia, Universitat de Barcelona, Avgda. Diagonal 645, 08028 Barcelona

\section{Sergi Sabater}

Institut d'Ecologia Aquàtica, Departament Ciències Ambientals, Universitat de Girona, Campus de Montilivi 17071Girona, Spain

\begin{abstract}
We investigated the effect of benthic substratum type (sand and rocks) and nutrient supply ( $\mathrm{N}$ and $\mathrm{P}$ ) on biofilm structure and heterotrophic metabolism in a field experiment in a forested Mediterranean stream (Fuirosos). Rock and sand colonization and biofilm formation was intensively studied for $44 \mathrm{~d}$ at two stream reaches: control and experimental (continuous addition of phosphate, ammonia, and nitrate). Structural (C, N, and polysaccharide content and bacterial and chlorophyll density) and metabolic biofilm parameters ( $\beta$-glucosidase, peptidase, and phosphatase enzyme activities) were analyzed throughout the colonization process. The epilithic biofilm (grown on rocks) had a higher peptidase activity at the impacted reach, together with a higher algal and bacterial biomass. The positive relationship between the peptidase activity per cell and the $\mathrm{N}$ content of the epilithic biofilm suggested that heterotrophic utilization of proteinaceous compounds from within the biofilm was occurring. In contrast, nutrient addition caused the epipsammic biofilm (grown on sand) to exhibit lower $\beta$-glucosidase and phosphatase activities, without a significant increase in bacterial and algal biomass. The differential response to nutrient addition was related to different structural characteristics within each biofilm. The epipsammic biofilm had a constant and high $\mathrm{C}: \mathrm{N}$ ratio (22.7) throughout the colonization. The epilithic biofilm had a higher $\mathrm{C}: \mathrm{N}$ ratio at the beginning of the colonization (43.2) and evolved toward a more complex structure (high polysaccharide content and low $\mathrm{C}: \mathrm{N}$ ratio) during later stages. The epipsammic biofilm was a site for the accumulation and degradation of organic matter: polysaccharides and organic phosphorus compounds had higher degradation activities.
\end{abstract}

Microorganisms play a key role in the degradation of organic matter and the associated release of energy in stream ecosystems (Meyer 1994). Microbial communities feed on allochthonous (dissolved and particulate plant and animal materials) and/or autochthonous organic matter (algal detritus and exudates) and are the main factor responsible for river C cycling (Allan 1995). In low-order streams, the benthic community is the most important site for organic matter cycling. In most cases, rock, cobbles, sand, and wood coexist in a stream reach, and all of these substrata host biofilms with differing structural characteristics (Lock 1993). In association with these structural differences, there are also significant differences in photosynthetic activity, biofilm thick-

\section{Acknowledgments}

We thank two anonymous reviewers for their helpful suggestions about the manuscript. Comments by E. Garcia Berthou and C. Freeman are very much appreciated.

This study was funded by grant CICYT REN2002-04442-C0202/GLO of the Spanish Science Ministry. A.G. received AECI and CONICET grants to participate in this project. ness, bacterial density, and enzyme activities (Romaní and Sabater 2001). Organic carbon recycling within the biofilm (Wetzel 1993) can reduce the dependence of the biofilm on the availability of organic carbon in the overlying river water (Freeman and Lock 1995). These structural and metabolic differences have significant implications for the rate of organic matter cycling in a fluvial ecosystem. Where structural differences are substantial, there may be substantial effects on ecosystem processes, because habitat heterogeneity affects the outcome of numerous ecological functions via physical and biological factors (Cardinale et al. 2002).

Nutrient availability can affect biofilm heterotrophic functioning either directly, by influencing nutrient uptake (Caron 1994), or indirectly, through an effect on primary producers (e.g., Romaní and Sabater 2000; Francoeur 2001; Rier and Stevenson 2002). Benthic autotrophs and heterotrophs respond differently to nutrient enrichment (Mulholland et al. 1991; Hillebrand et al. 2002) and depending on the substratum type (solid substratum vs. sediment; Blumenshine et al. 1997). These differential responses to nutrient enrichment may be related to the nutrient status of the biofilm. The un- 
derlying question being tested in the present article is whether the structural-functional characteristics of river biofilms colonizing different substratum types determine their nutrient status, and as a consequence, their response to nutrient enrichment.

The colonization by biofilms of streambed substrata has been described as a sequence of several overlapping stages (Stock and Ward 1989) resulting from the progressive response of the organisms to physical (light, temperature, and water current) and chemical (nutrients) factors. Intensive investigation of the colonization process, by both metabolic (extracellular enzyme activities) and structural parameters, under different nutrient conditions and substratum type (sand and rock), may be an appropriate tool to define how structural biofilm characteristics influence its metabolic outcome. We have taken this approach to determine the extent to which the structural and metabolic changes in rock and sand biofilms are associated with differing nutrient conditions. The study was performed in an oligotrophic forested Mediterranean stream. Biofilm colonization was monitored intensively over a 44-d period. Light is a limiting factor in forested streams, but, during short periods when leaves are absent, the entry of light may be sufficient to support the primary producers (Hill 1996). The present study was performed during one of these periods, at the beginning of spring. The biofilm structure $(\mathrm{C}: \mathrm{N}$ ratio, polysaccharide content, and algal and bacterial density) and metabolism (extracellular enzyme activities) were monitored in two stream reaches, each of which received different nutrient inputs. Specifically, the following questions were asked. (1) How would the structural descriptors ( $\mathrm{C}$ and $\mathrm{N}$ content and algal and bacterial density) of rock and sand biofilms differ throughout the colonization when submitted to the different nutrient inputs? (2) What would the relationship between biofilm structure and organic matter use (extracellular enzyme activities) be under the different conditions and biofilm type? (3) What would the relevance of sand and rock substrata be in the different river reaches (control/impacted) in terms of the overall organic matter cycling in the river?

\section{Study area}

Fuirosos is a third-order stream located in Montnegre-Corredor Natural Park, a forested range close to the Mediterranean Sea (50 km north of Barcelona in northeast Spain). The annual average water flow ranges 5-20 L s${ }^{-1}$, but permanent flow usually ceases from July until September. $\mathrm{Nu}-$ trient content is low: annual average values for 2001 were $18.1 \mu \mathrm{g} \mathrm{P}_{-} \mathrm{PO}_{4} \mathrm{~L}^{-1}, 664.9 \mu \mathrm{g} \mathrm{N}^{-N_{3}} \mathrm{~L}^{-1}$, and $68.3 \mu \mathrm{g} \mathrm{N}-$ $\mathrm{NH}_{4} \mathrm{~L}^{-1}$ (V.A. unpubl. data).

Two reaches $50 \mathrm{~m}$ in length were defined in Fuirososan upstream, control reach and an immediate downstream reach, which was artificially fertilized and considered to be impacted. The streambed morphology was very similar in the two studied reaches, which were characterized by the alternation of riffles and pools. Riffles were dominated by boulders and cobbles, and sand was abundant in pools. Branches and leaves were scattered throughout the stream bed, particularly in the littoral and slow-moving areas. At
Table 1. Physical and chemical characteristics of Fuirosos water at the control and impacted reaches during the study period. Values are means and SD of $8 \mathrm{~d}$ of sampling.

\begin{tabular}{|c|c|c|c|c|}
\hline \multirow[b]{2}{*}{$\mathrm{P}_{-} \mathrm{PO}_{4}\left(\mu \mathrm{g} \mathrm{L}^{-1}\right)$} & \multicolumn{2}{|c|}{ Control reach } & \multicolumn{2}{|c|}{ Impacted reach } \\
\hline & 8.9 & $(0.2)$ & 454.7 & $(256.2)$ \\
\hline $\mathrm{N}-\mathrm{NH}_{4}\left(\mu \mathrm{g} \mathrm{L}^{-1}\right)$ & 39.1 & $(7.2)$ & 665.3 & $(410.2)$ \\
\hline $\mathrm{N}-\mathrm{NO}_{3}\left(\mu \mathrm{g} \mathrm{L}^{-1}\right)$ & 336.9 & $(157.7)$ & 1685.6 & $(670.0)$ \\
\hline $\mathrm{DOC}\left(\mathrm{mg} \mathrm{L}^{-1}\right)$ & 2.45 & $(0.17)$ & \multicolumn{2}{|c|}{ ND } \\
\hline $\mathrm{BDOC}\left(\mathrm{mg} \mathrm{L}^{-1}\right)$ & 0.13 & $(0.08)$ & \multicolumn{2}{|c|}{ ND } \\
\hline $\mathrm{pH}$ & 7.4 & $(0.2)$ & 7.4 & $(0.1)$ \\
\hline Temperature $\left({ }^{\circ} \mathrm{C}\right)$ & 6.3 & (1.1) & 6.5 & (1.1) \\
\hline $\mathrm{O}_{2}\left(\mathrm{mg} \mathrm{L}^{-1}\right)$ & 11.4 & $(0.3)$ & 11.6 & $(0.2)$ \\
\hline Conductivity $\left(\mu \mathrm{S} \mathrm{cm}^{-1}\right)$ & 248.7 & $(46.6)$ & 255.4 & (5.4) \\
\hline Light $\left(\mu \mathrm{mol} \mathrm{m} \mathrm{m}^{-2} \mathrm{~s}^{-1}\right)$ & 52.01 & $(28.69)$ & 51.85 & $(26.91)$ \\
\hline Current $\left(\mathrm{m} \mathrm{s}^{-1}\right)$ & 0.015 & $(0.011)$ & 0.054 & $(0.068)$ \\
\hline
\end{tabular}

ND: not done.

this site, the stream was 3-4 $\mathrm{m}$ wide and $\sim 10-50 \mathrm{~cm}$ deep. Riparian vegetation was mainly made up of sycamores (Platanus x hispanica), alders (Alnus glutinosa), and black poplar (Populus nigra).

\section{Methods}

Sampling strategy-Unglazed ceramic tiles $\left(0.64 \mathrm{~cm}^{2}\right)$ were used as substrata for epilithic biofilm colonization. These substrata were glued onto flat surfaces of clean rocks from the stream (60-100 tiles on each rock) and placed in the stream. Eight different rocks with glued tiles were deployed in the upstream and downstream reaches. Epipsammic biofilm developed on stream sand that had been previously precombusted in the laboratory $\left(4 \mathrm{~h}\right.$ at $\left.450^{\circ} \mathrm{C}\right)$. The sand was placed in aluminium foil plates $(20 \times 10 \mathrm{~cm}, 4 \mathrm{~cm}$ depth $)$, and eight plates were deployed at each stretch. Fine holes ( $\sim 1 \mathrm{~mm}$ diameter) were made at the two sites of each plate, facing upstream and downstream, to favor water flowing through the sediment. Rocks with tiles and plates with sand were immersed at random in the two defined stretches (control and impacted).

Nutrient enrichment was achieved by the addition of ammonium phosphate and ammonium nitrate, causing the basal concentration (control reach) to increase 60 times for phosphate, 4 times for nitrate, and 18 times for ammonia (Table 1). The additions started on 14 January 2002 and extended for $44 \mathrm{~d}$. The enriched solution was stored in a 50-liter carboy (flowing continuously at $12 \mathrm{ml} \mathrm{min}^{-1}$ ) placed in a small waterfall, to ensure a complete mixing with the downstream water. Physical and chemical conditions in the upstream and downstream stretch were monitored weekly.

The colonizing substrata (tiles and sand) at the two reaches were collected on days $1,2,3,4,7,9,14,21,29$, and 44. Day 0 was 14 January 2002, when the substrata were immersed. Sampling of tiles was performed at random from the different rocks. Tiles were separated from different rocks with a spatula, and sand samples were collected from different plates with an untapped syringe (accounting for 1-2 $\mathrm{ml}$ of sand volume). Enzymatic activities were measured after returning to the laboratory, whereas samples for chlorophyll, C, N, and polysaccharide content were frozen until 
analysis. Samples for algal and bacterial density were preserved with formalin. At day 42, sand samples and cobbles from the riverbed were collected for the analysis of chlorophyll and bacterial density in natural substrata in comparison to the colonizing substrata.

Physical-chemical parameters-Oxygen (oxygen meter; WTW), $\mathrm{pH}$ (pH meter; WTW), conductivity (conductivity meter; WTW), temperature (WTW meters), light (quantum sensor Li-192SB; Li-Cor), and current velocity (Schiltknecht 43221; MiniAir2) were measured once a week in the field. Water samples for nutrient content were collected in triplicate at the control and impacted reaches. Water samples for dissolved organic carbon (DOC; three replicates) and biodegradable DOC (BDOC; five replicates) were only collected at the control reach. All water samples were filtered (precombusted glass-fiber filters; Whatman) before analysis. Ammonium, nitrite, nitrate, and dissolved phosphorus were analyzed according to standard methods (American Public Health Association 1989). DOC was measured using a total organic carbon analyzer (TOC-5000; Shimadzu). The BDOC was measured according to the procedure of Servais et al. (1989). Samples were incubated immediately after sampling and for $28 \mathrm{~d}$ at room temperature $\left(20-24^{\circ} \mathrm{C}\right)$, in the dark. The glass flasks and ampoules used had been previously heated for $4 \mathrm{~h}$ at $550^{\circ} \mathrm{C}$, to ensure complete organic carbon release from the glassware. All DOC samples were fixed with sodium azide $\left(2.7 \mathrm{mmol} \mathrm{L}{ }^{-1}\right)$ and preserved at $4^{\circ} \mathrm{C}$ until analysis.

Chlorophyll concentration and algal community densityThe chlorophyll density on tiles and sand (three replicates for each reach) was measured after extraction in $90 \%$ acetone and sonication for $4 \mathrm{~min}(40 \mathrm{~W}$ power and $40 \mathrm{kHz}$ frequency; Selecta). A second and third extraction was sometimes necessary to achieve total extraction. The chlorophyll concentration was determined spectrophotometrically (Lambda UV/VIS spectrophotometer; Perkin-Elmer) after filtration (GF/C; Whatman) of the extract according to the method of Jeffrey and Humphrey (1975). The composition and density of the algal community were estimated by counting under an inverted microscope after the sonication of sand or tiles (2 min) and subsequent sedimentation of cells. Results were the average of three replicates (sand or tiles).

Bacterial density-Bacterial density was estimated in triplicate after sonication (at $2 \mathrm{~min}, 40 \mathrm{~W}$ power, $40 \mathrm{kHz}$ frequency). Scanning electron microscope observations of sonicated sand and tiles certified that the detachment efficiency accounted for the $80-90 \%$ of the bacterial cells. A larger sonication time resulted in extensive lysis of bacterial cells. After appropriate dilution, fixed samples were stained for 5 min with DAPI (4,6-diamidino-2-phenyilindole; final concentration of $2 \mu \mathrm{g} \mathrm{ml}^{-1}$ ) filtered through $0.2 \mu \mathrm{m}$ irgalan black stained polycarbonate filters (Nuclepore), and bacteria were counted using a fluorescence microscope (Nikon) under $\times 1,250$ magnification. Fifteen fields were counted per filter, for a total of 400-800 organisms.
Carbon and nitrogen biofilm content-Sand and tiles colonized by biofilms (three replicates for each stream reach) were thawed, the $5 \mathrm{ml}$ of distilled water was added, sonicated (4 min), and the was extract filtered (on precombusted and preweighted filters Whatman glass-fiber filters). Two to three successive extractions, were performed to ensure total extraction of the colonized biofilm. Filters were dried (for 2 $\mathrm{d}$ at $110^{\circ} \mathrm{C}$ ) and analyzed for carbon and nitrogen with a C/ N Analyzer 1500 (Carlo Erba), with vanadium pentoxide used as the oxidation catalyzer.

Polysaccharide biofilm content-Total biofilm carbohydrates were measured using the phenol-sulphuric assay (Dubois et al. 1956). A sand sample or a tile was used for each analysis. After the extraction, samples were filtered (on precombusted Whatman glass-fiber filters), and the absorbance was measured at $485 \mathrm{~nm}$ against a reagent blank. Standards of glucose $\left(0-200 \mu \mathrm{g} \mathrm{ml}^{-1}\right)$ were also prepared. Results are given as glucose equivalents.

Extracellular enzyme activities - The extracellular enzyme activities of $\beta$-glucosidase (EC 3.2.1.21), leucine-aminopeptidase (EC 3.4.11.1), and phosphatase (EC 3.1.3.1-2) were measured by using fluorescent-linked substrates (methylumbelliferyl [MUF] and with aminomethyl-coumarin [AMC] used for peptidase). Colonized tiles and sand samples were incubated for $1 \mathrm{~h}$ in the dark at river temperature immediately after sampling. Incubations were performed at a final concentration of $300 \mu \mathrm{mol} \mathrm{L}{ }^{-1}$ (a saturation concentration for these communities). Blanks and standards of MUF and AMC $\left(0-100 \mu \mathrm{mol} \mathrm{L}^{-1}\right)$ were also incubated. At the end of the incubation, Glycine buffer ( $\mathrm{pH} 10.4)$ was added (1/1 vol/ $\mathrm{vol}$ ), and the fluorescence was measured at $365 / 455 \mathrm{~nm}$ excitation/emission for MUF and at 364/445 nm excitation/ emission for AMC. Values are expressed as nanomoles of MUF per square centimeter of biofilm surface area and also as nanomoles of MUF per bacterial cell (in the case of $\beta$ glucosidase and peptidase activities).

Statistical analysis-Biomass and activities of the epilithic and epipsammic biofilms were analyzed by using a 2-way repeated-measures analysis of variance (ANOVA) to test for the differences between substrata (sand and rock) and treatment (control and impacted) and the interaction between substrata and treatment. Probabilities within groups (day and interactions) were corrected for sphericity using the Greenhouse-Geisser correction. All probabilities were adjusted by the Dunn-Sidak correction. Although the treatment factor (control vs. impacted) was subjected to one stream, the sand and tiles replicate samples taken for each analysis were independent, because they were randomly collected from different rocks and sand plates.

$\beta$-glucosidase and peptidase activities per bacterial cell were calculated as the mean activity value divided by the mean bacterial cell number. Therefore, these were single observations per treatment for each sampling date, which could not be included into a two-way ANOVA. Results of the polysaccharide content (simple values) were included in an ANOVA. To test for differences in these cases, $t$-test analyses of paired values were performed. 

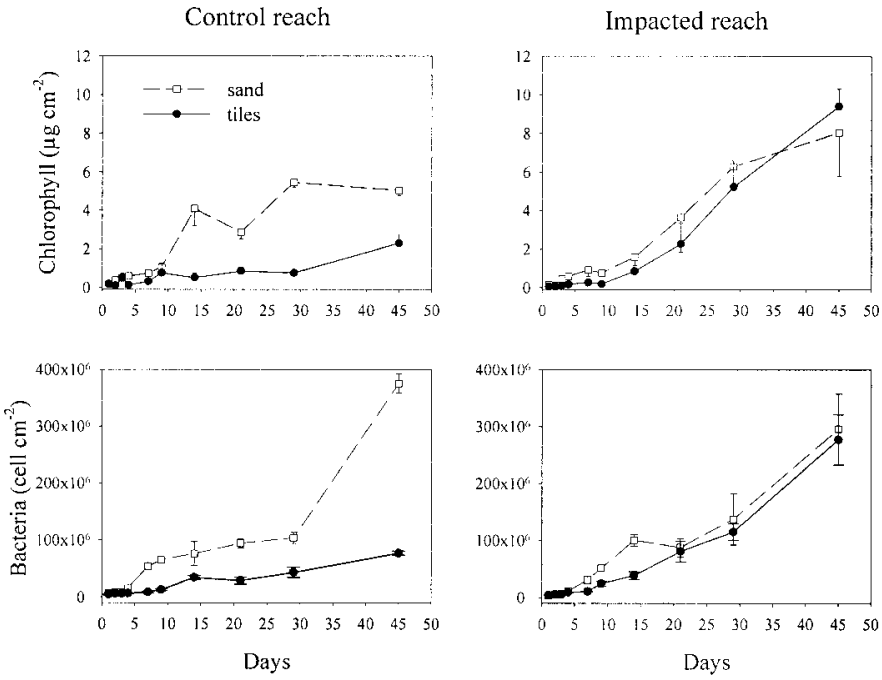

Fig. 1. Chlorophyll and bacterial density in the colonizing tiles and sand at the control and impacted reach in Fuirosos stream. Values are means $\pm \operatorname{SE}(n=3)$.

The structural and metabolic characteristics at the end of the colonization period (44 d) for the epilithic and epipsammic biofilms were compared by two-tailed $t$-tests.

The relationships between the $\mathrm{C}$ and $\mathrm{N}$ content of the biofilm and glucosidase or peptidase per cell were analyzed by linear regression after logarithmic transformation of the data. Model II linear regression (geometric mean regression) was used, because both variables used for the regression were measurements (with errors; Sokal and Rohlf 1995).

\section{Results}

Physical-chemical results-The control and impacted reaches at Fuirosos stream were characterized by low water temperature $\left(6.3-6.5^{\circ} \mathrm{C}\right)$ and a mean conductivity of $249-$ $255 \mu \mathrm{S} \mathrm{cm}^{-1}$ during the study period (January-March 2002; Table 1). The maximum incident light on the river bottom during daylight ranged 10-110 $\mu \mathrm{mol}$ photons $\mathrm{m}^{-2} \mathrm{~s}^{-1}$, but total light accounted for $0.5-1.5 \mathrm{~mol}$ photons $\mathrm{m}^{-2} \mathrm{~d}^{-1}$. Nutrients were low in the control reach and reached high levels because of the nutrient addition to the impacted reach (Table 1). The $\mathrm{N}: \mathrm{P}$ molar ratio was $\sim 45$ in the control reach and decreased to 16 in the impacted reach. Current velocity at the colonizing sand and tiles was not significantly different at both reaches and ranged $1.5-5 \mathrm{~cm} \mathrm{~s}^{-1}$. Mean discharge during the study period was $25.2 \mathrm{~L} \mathrm{~s}^{-1}$ (minimum 22.3 and maximum $28.8 \mathrm{~L} \mathrm{~s}^{-1}$ ). There were no sudden variations of flow during the period of study.

Bacterial abundance and algal chlorophyll-Chlorophyll and bacterial density at the end of the colonization sequence (Fig. 1) where in the same range than those obtained for natural sand (at the control and impacted reach, $1.04 \pm 0.26$ and $1.08 \pm 0.10 \times 10^{8}$ bacterial cells $\mathrm{cm}^{-2}$ and $1.67 \pm 0.21$ and $4.74 \pm 1.76 \mu \mathrm{g}$ chorophyll $\mathrm{cm}^{-2}$, respectively) and for natural cobbles (at the control and impacted reach, $0.55 \pm$ 0.39 and $1.35 \pm 0.15 \times 10^{8}$ bacterial cells $\mathrm{cm}^{-2}$ and 6.65 \pm 2.55 and $20.7 \pm 10.6 \mu \mathrm{g}$ chorophyll $\mathrm{cm}^{-2}$, respectively) collected on day 42 (February 2001).

A higher bacterial density was achieved in the sand than in the rocky substrata (Fig. 1). After day 7 of colonization, there was a higher increase in bacterial density in sand than in rocks. The results of the repeated-measures ANOVA showed highly significant differences between substrata and the interaction of day with substrata (Table 2). The interaction of day with substrata with treatment (Table 2) indicated the different time evolution of bacterial density in epilithic and epipsammic biofilms depending on the treatment; the epipsammic biofilms showed no differences between reaches, whereas it was faster for the epilithic biofilm of the impacted reach (Fig. 1).

The dynamics of chlorophyll density on the tiles and sand followed a similar temporal pattern to that already described for the bacteria (Fig. 1). Differences between both substrata were significant throughout the colonization (repeated-measures ANOVA; Table 2), chlorophyll being significantly higher in the epipsammon than in the epilithon. The different evolution of chlorophyll density at the two reaches is expressed by the significant interaction of day with treatment, showing a higher increase in chlorophyll at the impacted reach after day 15 of colonization (Fig. 1, Table 2).

Differences in chlorophyll corresponded with differences in algal density but not with a different community composition (Table 3). Diatoms of the genera Achnanthes, Fragilaria, and Gomphonema were the dominant algae throughout the colonization. Similar species composition was observed for the two substrata (Table 3). Decaying diatoms were most commonly observed in the epipsammic biofilm.

The polysaccharide content of the biofilms was very low and highly variable during the early days of colonization (1$4)$. The polysaccharide content per surface area ( $\mu$ g glucose equivalent $\mathrm{cm}^{-2}$ ) was significantly higher in the epipsammic biofilm (paired $t$-test, $p=0.0001$; Fig. 2). However, the polysaccharide content per percentage of biofilm carbon was significantly higher in the epilithic biofilm (paired $t$-test, $p$ $=0.02$ ). The biofilm polysaccharide content was slightly lower in the impacted than in the control reach.

Biofilm $C$ and $N$ content and $C: N$ ratio-The epipsammic biofilm had a higher $\mathrm{C}$ and $\mathrm{N}$ content than the epilithic (Fig. $3)$. The results of ANOVA showed significant differences between substrata. The interaction of day with substrata $(\mathrm{Ta}-$ ble 2) showed that the increase of $\mathrm{N}$ and especially $\mathrm{C}$ in sand was significant beginning on day 14 of colonization. However, there was a more regular increase in the $\mathrm{N}$ and $\mathrm{C}$ content of the epilithic biofilms. The evolution of $\mathrm{N}$ content was slightly different between the control and impacted reaches (Table 2; interaction of day with treatment). A major increase in $\mathrm{N}$ content at the impacted reach was observed at the end of the colonization period (days 29 and 44). Slightly lower $\mathrm{C}: \mathrm{N}$ ratios (but not significantly different) characterized the two biofilm types at the impacted reach at the end of the colonization sequence.

The evolution of the $\mathrm{C}: \mathrm{N}$ molar ratio of the biofilms throughout the colonization was significantly different between the two substrata types (Fig. 3, Table 2; interaction of day with substrata). In the epilithic biofilm, the $C: N$ molar 


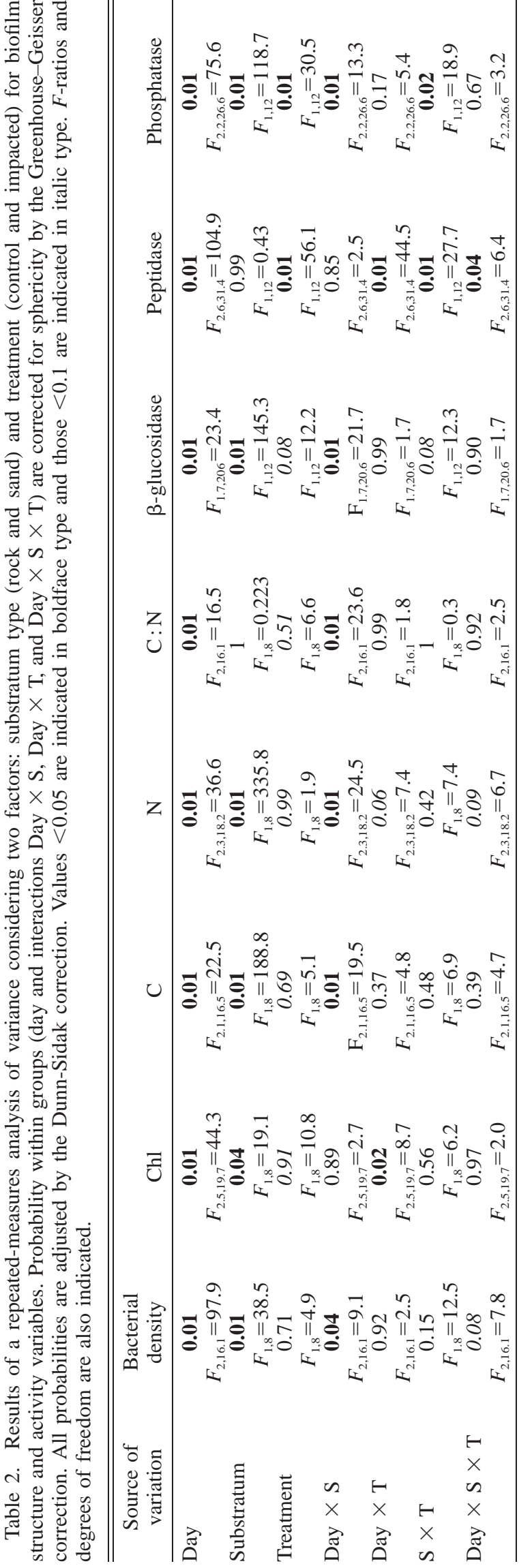

ratio was high at the beginning of the colonization and decreased to 11.2 (control) and 9.9 (impacted). However, the $\mathrm{C}: \mathrm{N}$ ratio was rather constant in the epipsammic biofilm, ranging 20.8-27.2 at the control reach and 18.4-25.0 at the impacted reach. The $\mathrm{C}: \mathrm{N}$ ratio was significantly higher in the epipsammon than in the epilithon at the end of the colonization ( $t$-test, $p<0.01)$.

Extracellular enzyme activities-The activities of $\beta$-glucosidase and phosphatase (Fig. 4) were higher in the epipsammic than in the epilithic biofilm (ANOVA; Table 2). Peptidase activities were not significantly different between substrata (Fig. 4, Table 2; ANOVA). Significantly higher activities of phosphatase and $\beta$-glucosidase occurred at the control reach. In contrast, peptidase activities were significantly higher at the impacted reach. The significant interaction between substratum and treatment (Table 2) indicates a different response depending on the substratum. In the case of peptidase, there were slight differences between the control and impacted reaches in the epipsammic biofilm, but, for the epilithon, the activity was much higher in the impacted reach. The activities of phosphatase and $\beta$-glucosidase of the epipsammic biofilm were higher at the control reach but were similar in the epilithon between the control and impacted reaches.

The level of $\beta$-glucosidase activity per bacterial cell was significantly higher in the epipsammic than in the epilithic biofilms of the two studied reaches ( $t$-test of paired values, $p<0.001$; Fig. 5). However, differences were not significant for the peptidase activity per cell ( $t$-test of paired values, $p$ $=0.31$ and $p=0.72$ for the control and impacted reach, respectively). $\beta$-glucosidase activity per cell was higher in the control than in the impacted reach $(p=0.09$ for sand and $p=0.048$ for tiles). Peptidase activity per cell was significantly higher at the impacted than at the control reach in the epilithic biofilm ( $p=0.027)$ but was not significantly different for the epipsammic biofilm $(p=0.27)$.

Structural-metabolic relationships-Significant relationships were found between the $\mathrm{C}$ content of the biofilms and the $\beta$-glucosidase activity per cell (Fig. 6). The epipsammic biofilm showed a positive linear regression between these two descriptors (model II, $r=0.48, p=0.033$ ), whereas, in the epilithic, this relationship was negative (model II, $r$ $=-0.45, p=0.033)$. A significant linear regression was also established between the $\mathrm{N}$ content of the epilithic biofilm and the peptidase activity per cell (model II, $r=0.71$, $p<0.0005$; Fig. 6), but this relationship was not significant in the epipsammic biofilm (Fig. 6).

\section{Discussion}

The general question formulated in our study was whether nutrient enhancement could differentially influence the structure and function of biofilms colonizing different stream substrata. The contrasting behavior of the extracellular enzyme activities in the epilithic and epipsammic biofilms indicated different mechanisms of organic matter use in response to the nutrient addition. The extracellular enzyme activities ( $\beta$ glucosidase, leucine-aminopeptidase, and phosphatase) mea- 
Table 3. Relative abundance of the most abundant algal species on the epilithic and epipsammic biofilms in the control and impacted reaches in Fuirosos. Algal cell density is also shown. Values are averages after $44 \mathrm{~d}$ of colonization $(n=3)$ and SD (in parentheses).

\begin{tabular}{|c|c|c|c|c|}
\hline & \multicolumn{2}{|c|}{ Control reach } & \multicolumn{2}{|c|}{ Impacted reach } \\
\hline & Sand & Rock & Sand & Rock \\
\hline Achnanthes biasolettiana Grun. & $3.7(11.2)$ & $19.0(50.6)$ & $5.8(3.9)$ & $36.7(21.4)$ \\
\hline Amphora libyca Ehr. & $1.2(0.7)$ & $0.6(0.7)$ & $0.5(0.6)$ & 0.0 \\
\hline Achnanthes lanceolata (Breb.) Grun. & 0.0 & $1.4(3.0)$ & 0.0 & 0.0 \\
\hline Cocconeis placentula Ehr. & $2.2(2.1)$ & $1.1(0.6)$ & $0.9(1.1)$ & $0.2(0.9)$ \\
\hline Diploneis oblongella (Naegeli) Cleve-Euler & $4.2(8.4)$ & $3.8(2.4)$ & $9.5(12.9)$ & $21.0(28.7)$ \\
\hline Eunotia sp. & $1.1(2.7)$ & $1.7(2.4)$ & $3.9(4.6)$ & 0.0 \\
\hline Fragilaria ulna (Nitzsch.) Compère & $16.3(6.9)$ & $7.1(2.0)$ & $12.7(5.6)$ & $0.7(1.3)$ \\
\hline Gomphonema angustatum (Kützing) Rabh. & $65.4(55.8)$ & $59.7(28.4)$ & $44.8(26.9)$ & $35.7(41.7)$ \\
\hline Melosira varians Agardh & 0.0 & 0.0 & $4.7(8.5)$ & 0.0 \\
\hline Meridion circulare (Greville) C.A.Agardh & 0.0 & $0.4(0.9)$ & $2.5(5.4)$ & $0.3(0.5)$ \\
\hline Navicula cryptocephala Kütz. & $0.9(2.1)$ & $0.8(1.3)$ & $1.3(1.6)$ & $0.4(0.2)$ \\
\hline N. capitata var. hungarica (Grun.) ross & 0.0 & $0.9(0.9)$ & $10.4(24.7)$ & 0.0 \\
\hline Nitzschia fonticola Grun. Cleve et Möller & $3.0(6.3)$ & $1.1(0.9)$ & $1.5(1.9)$ & $2.9(0.5)$ \\
\hline N. linearis (Agardh) W.M.Smith & $0.7(1.8)$ & $1.4(3.1)$ & $0.7(0.4)$ & $0.4(0.8)$ \\
\hline Gongrosira sp. & 0.0 & 0.0 & 0.0 & $1.5(2.7)$ \\
\hline Algal cell density (cells $\times 10^{6} \mathrm{~cm}^{-2}$ ) & $0.9(0.2)$ & $0.3(0.1)$ & $1.9(0.7)$ & $6.0(0.7)$ \\
\hline
\end{tabular}

sured during colonization accounted for the use of cellobiose molecules ( $\beta$-glucosidase; Deshpande and Eriksson 1988), peptides, and proteins of the organic $\mathrm{N}$ pool (leucine-aminopeptidase) and organic phosphorus (phosphatase; Chróst 1991). These enzymatic activities represent a reasonable surrogate of the transformation dynamics by the heterotrophs (Karner and Rassoulzadegan 1995). As a consequence, they may be taken as good indicators of nutrient availability (Sala et al. 2001), as well as of detectors of small-scale variations of organic matter use (Romaní and Marxsen 2002).

The epilithic biofilm of the impacted reach showed a clear increase in peptidase activity together with the increase in chlorophyll and bacterial density. Our results indicate that the increase in biomass in the epilithic biofilm enhanced the
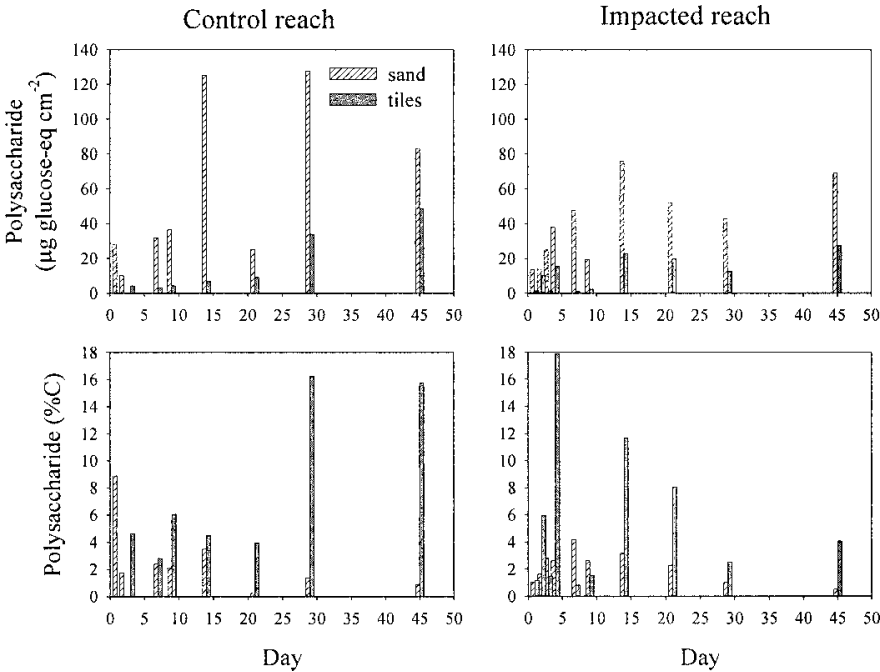

Fig. 2. Polysaccharide biofilm content of biofilm colonizing tiles and sand at the control and impacted reaches in the Fuirosos stream. Simple values (bars) are expressed as $\mu$ g glucose equivalent per $\mathrm{cm}^{2}$ of biofilm and as the percentage of $\mathrm{C}$ in the biofilm. heterotrophic use of proteinaceous compounds, especially from within the biofilm, to obtain $\mathrm{N}$ and $\mathrm{C}$. The epipsammic biofilm did not show any increase in algal or bacterial biomass in response to the nutrient addition but did show a decrease in the activities of $\beta$-glucosidase and especially phosphatase. It might be considered that the enzymatic re-
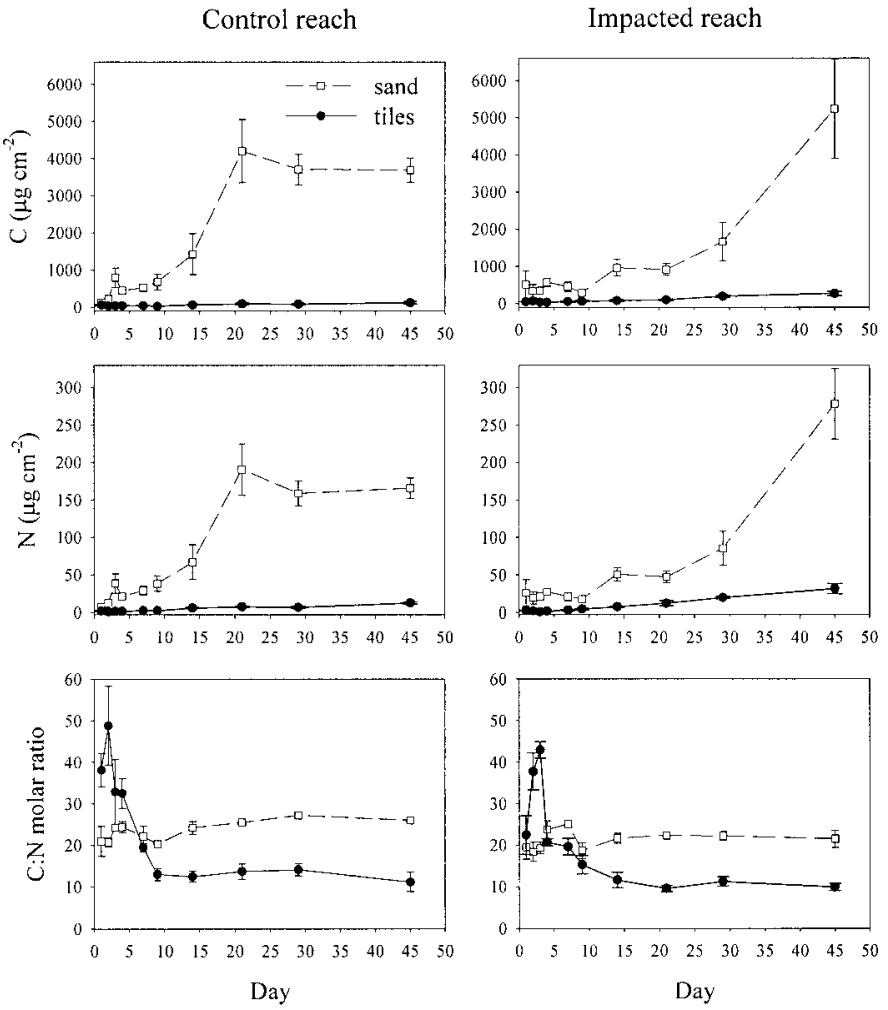

Fig. 3. $\mathrm{C}$ and $\mathrm{N}$ content and $\mathrm{C}: \mathrm{N}$ molar ratios of biofilm colonizing tiles and sand at the control and impacted reach in the Fuirosos stream. Values are the means $\pm \operatorname{SE}(n=3)$. 

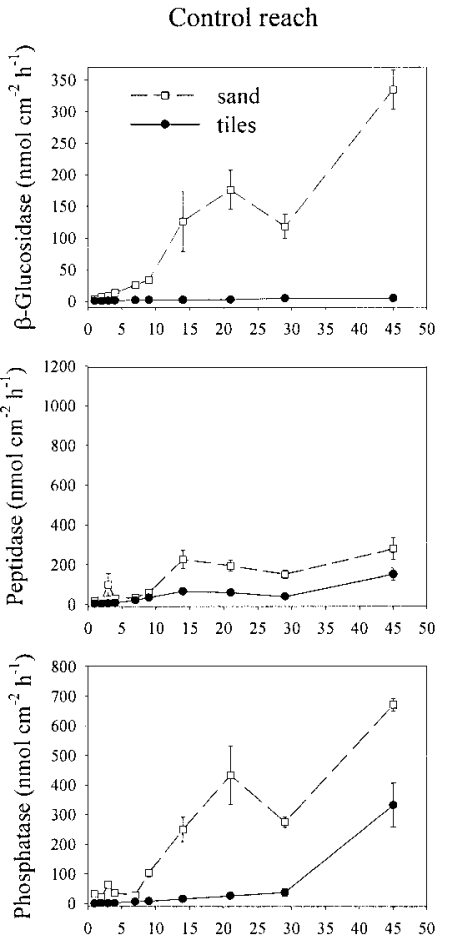

Days
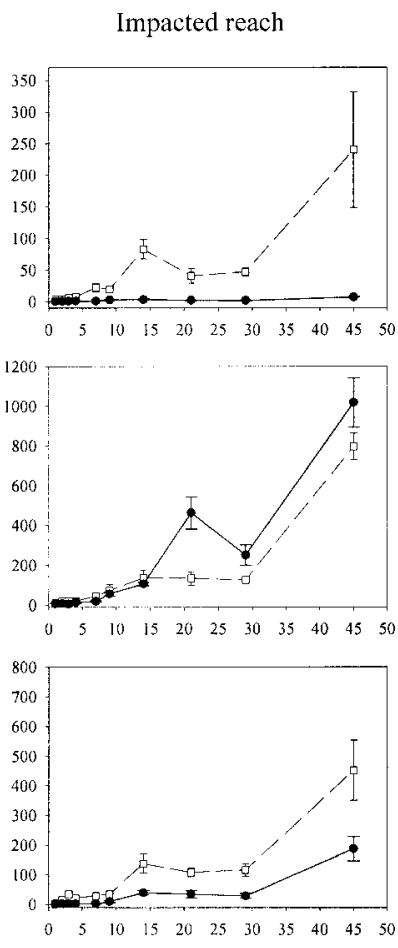

Days

Fig. 4. Extracellular enzymatic activities at the colonizing tiles and sand at the control and impacted reach in the Fuirosos stream. Values are means $\pm \operatorname{SE}(n=4)$.

sponse in the epipsammon is mainly a consequence of the nutrient content in the flowing water, which is especially significant for phosphatase. Moreover, the drastic increase in peptidase in the epilithic and the decrease in phosphatase in the epipsammic may be further influenced by the imbalanced addition (60 times for $\mathrm{P}$ and 20 times for $\mathrm{N}$ ), which was designed to reestablish $\mathrm{N}: \mathrm{P}$ values closer to the Redfield ratio.

The differential response of the epilithic and epipsammic biofilms may be related to structural and functional characteristics of each biofilm. Irrespective of the nutrient condition of the stream stretch, clear differences were observed throughout the colonization of both substrata. The epipsammic biofilm had higher $\beta$-glucosidase activity (both per area and per cell) than the epilithic biofilms throughout the colonization process, which indicates a much higher ability for the degradation of polysaccharide molecules. In previous studies, it has been shown that the higher activity of epipsammic biofilms was sustained under a variety of hydrological conditions (Romaní and Sabater 2001). The present study confirms the significant and positive relationship between $\beta$-glucosidase activity and carbon content as a characteristic feature of this biofilm. The superior ability of sand biofilms in processing cellobiose molecules may be related to two different mechanisms: a higher accumulation of organic matter in areas where sand is more abundant (usually littoral or pools), as well as around the sand grains; and the lower availability of labile molecules such as glucose, this being related to the type of materials accumulated (Chróst

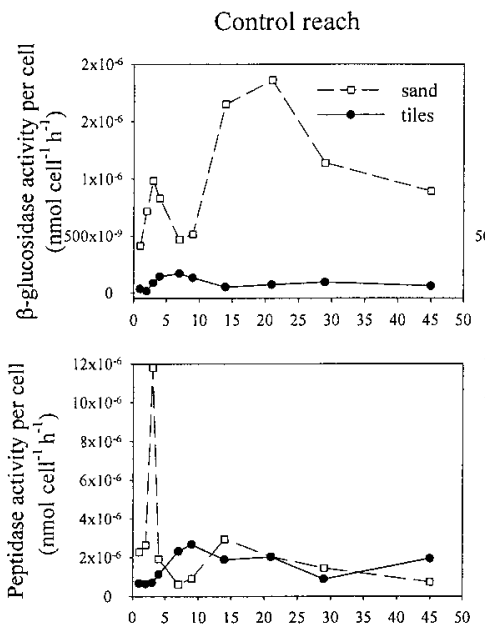

Day
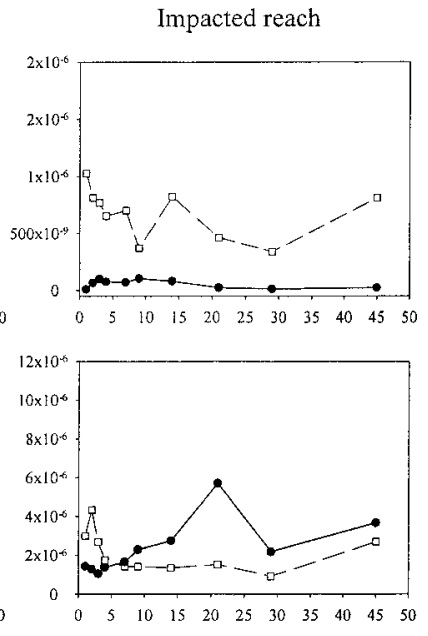

Day
Fig. 5. Activities of $\beta$-glucosidase and peptidase per bacterial cell in the colonizing tiles and sand at the control and impacted reach in the Fuirosos stream. Simple values are the result of the quotient between mean activity and mean bacterial density at each sampling day.

1989) in the depositional habitats where sand occurs. On the other hand, lower $\beta$-glucosidase activity (both per surface area and per cell) in the epilithic biofilm may be related to the greater supply of low-molecular-weight compounds from the algal community (algal exudates) to neighboring heterotrophs (Romaní and Sabater 2000), which could result in the inhibition of $\beta$-glucosidase activity on epilithic biofilms.

Differences regarding the biofilm type also occurred with
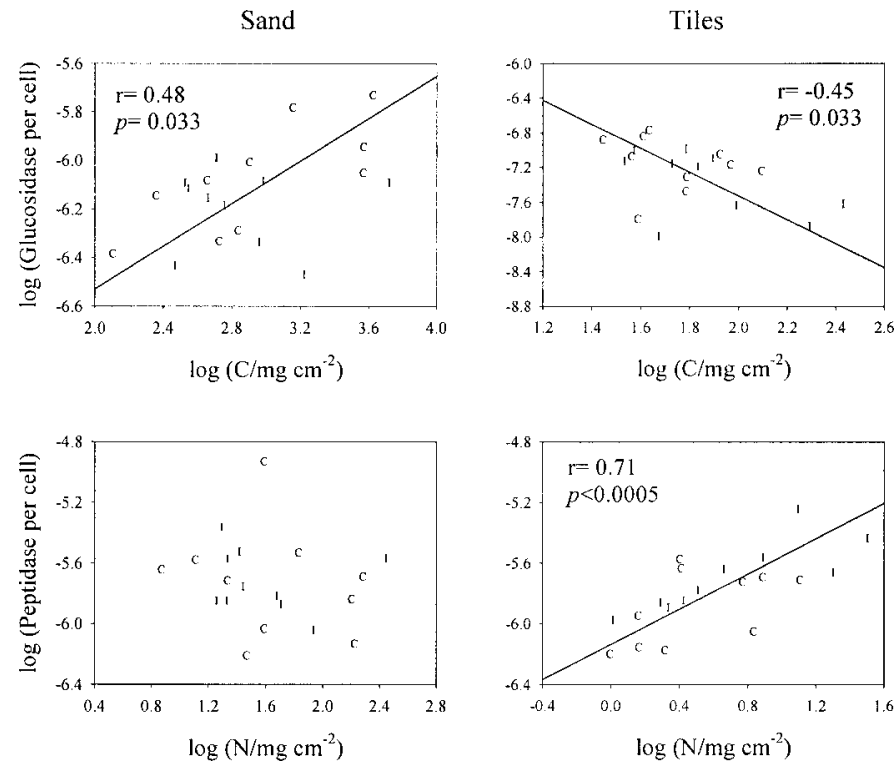

Fig. 6. Relationships between biofilm carbon and nitrogen content and the activities of $\beta$-glucosidase and peptidase per cell (in logarithms), respectively, for the epipsammic (on sand) and epilithic (on tiles) biofilms growing in the control (C) and impacted (I) reaches at the Fuirosos stream. Model II linear regressions (geometric mean regression) are expressed by solid lines. Correlation coefficients and probability values are also shown. 
respect to the use of organic phosphorus and organic nitrogen. The higher phosphatase activity in the epipsammic biofilm could be related to the organic matter pool accumulated (such as organic phosphorus compounds) in the sand. Differences between the two substrata were more reduced in the impacted reach. In the enriched conditions, the availability of inorganic phosphorus in the water could make unnecessary the activity of this enzyme (Perrin et al. 1987). On the other hand, the different relationship between peptidase activity per cell and the $\mathrm{N}$ content of the biofilm between the epilithic (positive) and the epipsammic (not significant) biofilms suggests a major use of nitrogenous organic molecules accumulated within the matrix of the epilithic biofilm. Probably as a consequence of internal biofilm cycling (Freeman and Lock 1995), the fresher material that had accumulated in the epilithic biofilm allowed for enhanced heterotrophic organic nitrogen utilization. The effect of algal-bacterial coupling on the leucine aminopeptidase activity in periphytic communities has been described by Francoeur and Wetzel (2003).

Temporal changes in the biofilm $\mathrm{C}: \mathrm{N}$ ratio and polysaccharide content reflect the differing structural complexity of the two biofilms. The $\mathrm{C}: \mathrm{N}$ ratio was practically constant in sand but decreased in rocks throughout the colonization period. The higher initial values of the $\mathrm{C}: \mathrm{N}$ ratio in the epilithic biofilm could be related to a higher adsorption of refractory materials by the artificial substrata (tiles). Moreover, the confluence between the epilithic and epipsammic C:N ratios on days 4-7 could be related to the formation of a primitive biofilm covering the surfaces (Lock 1993). In later stages, the progressive incorporation of algal and bacterial cells could be responsible for the relative increase in $\mathrm{N}$ content and its derived lower $\mathrm{C}: \mathrm{N}$ ratio in the epilithic biofilm. At this point, the epilithic biofilm showed a clear divergence with respect to the epipsammic biofilm. A higher proportion of polysaccharides probably reflects the structural complexity of epilithic biofilms (Stock and Ward 1989; Lock 1993). Instead, similarities between the $\mathrm{C}: \mathrm{N}$ ratios at the initial and then final stages of the sand colonization could be indicative of a biofilm hardly evolving from its simplicity. The rather low proportion of polysaccharides contrasts with the high number of algal and bacterial cells that colonize this substratum. It has to be considered that sand provides a large heterogeneity of surfaces as potential attachment sites (scanning electron microscopy observations, not shown) but also is associated with a high degree of physical instability. Therefore, even considering similar attachment patterns (Lawrence et al. 1995), the physical characteristics of the sand microenvironment could be determinant for this difference (Miller et al. 1987). It is also possible that the accumulation of detritic organic matter around the sand grains might be detrimental to the formation of a biofilm of similar complexity to that built on rocks.

The $\mathrm{C}: \mathrm{N}$ ratio may be taken as a good indicator of the influence of nutrient availability on the storage of nutrients (and, therefore, on survival and growth conditions) of the biofilms. The $\mathrm{C}: \mathrm{N}$ ratio has been demonstrated sensitive to be to the enhancement of nutrient supply (Peterson et al. 1993; Hillebrand and Kahlert 2001). However, changing the nutrient conditions caused only a slight decrease in the $\mathrm{C}$ :
$\mathrm{N}$ ratio (increase in $\mathrm{N}$ content) of Fuirosos biofilms. Stelzer and Lamberti (2002) observed that $\mathrm{C}: \mathrm{N}$ and $\mathrm{C}: \mathrm{P}$ ratios showed relative decreases after the addition of $\mathrm{N}$ or $\mathrm{P}$ under light saturation. The modest effects of nutrient addition to the $\mathrm{C}: \mathrm{N}$ ratio in Fuirosos may be related to the low light conditions characteristic of this forested stream (V.A. unpubl. data). The experiment was carried out in late winter and early spring, a period that corresponds in Mediterranean streams with a change in the light regime because of leafless riparian vegetation and frequent cloudless skies. However, light reaching the stream bed $\left(0.5-1.5 \mathrm{~mol}\right.$ photons $\left.\mathrm{m}^{-2} \mathrm{~d}^{-1}\right)$ was in subsaturating quantities for the primary producers (Roberts et al. in press). Sterner et al. (1997) determined that the positive relationship between the $\mathrm{C}: \mathrm{P}$ ratio in planktonic seston and phosphorus availability was modified by light conditions operating in a set of lakes. Olff (1992) also observed that the $\mathrm{C}: \mathrm{N}$ ratio of terrestrial grasses was related to the light: nitrogen ratio. It therefore follows that the imbalance of light with respect to other resources ( $\mathrm{N}$ and $\mathrm{P}$ in our study) could affect the elemental composition of biofilms, meaning that they are less likely to reflect the nutrient availability of the system. The study was completed during a period of relatively high light availability in the light-limited system; thus, this discrepancy may represent a permanent characteristic of the biofilms growing in this stream.

The present results show that the nature of the benthic substrata and their related variability at the habitat scale (substratum stability, roughness, and organic matter accumulation) are the major determinants of the structure of the biofilms and the nutrient status of the biofilm microorganisms. The streambed sand substratum can be described as a site of organic matter accumulation, which leads to a relatively high $\mathrm{C}: \mathrm{N}$ biofilm content, as well as to a high capacity for the degradation of polysaccharide and organic phosphorus. The absence of a dramatic increase in microbial biomass in sand, despite an increase in $\mathrm{P}$ and $\mathrm{N}$ in the river water, could also be indicative of carbon limitation in Fuirosos. This is suggested by the low availability of DOC in the flowing water (indicated by the low BDOC measured during the study period, which was $5 \%$ of DOC). Sand biofilms appeared to have $\mathrm{C}$ limitation both during the early stages of biofilm colonization before algal growth (Sobczak 1996) and in hyporheic sediments that received water with a low DOC content (Craft et al. 2002). In contrast, the epilithic biofilm had a comparatively more complex structure and a lower $\mathrm{C}: \mathrm{N}$ ratio. The rock substratum is a better site for building a structured biofilm, where algae and bacteria grow and increase their density because of the nutrient addition. The utilization of "high-quality organic matter" as a source of intrabiofilm $\mathrm{C}, \mathrm{N}$, and $\mathrm{P}$ creates a valuable capacity for sustained increases in microbial biomass after an addition of exogenous nutrients.

\section{References}

Allan, J. D. 1995. Stream ecology: Structure and function of running waters. Chapman \& Hall.

American Public Health Association. 1989. Standard methods for the examination of water and wastewater, 17th ed. American Public Health Association. 
Blumenshine, S. C., Y. Vadeboncoeur, And D. M. Lodge. 1997. Benthic-pelagic links: Responses of benthos to water-column nutrient enrichment. J. North Am. Benthol. Soc. 16: 466-479.

Cardinale, B. J., M. A. Palmer, C. M. Swan, S. Brooks, and N. L. Poff. 2002. The influence of substrate heterogeneity on biofilm metabolism in a stream ecosystem. Ecology 83: 412422.

CARON, D. A. 1994. Inorganic nutrients, bacteria, and the microbial loop. Microb. Ecol. 28: 295-298.

Chróst, R. J. 1989. Characterization and significance of $\beta$-glucosidase activity in lake water. Limnol. Oceanogr. 34: 660-672.

. 1991. Environmental control of the synthesis and activity of aquatic microbial ectoenzymes, p. 29-59. In R. J. Chrost [ed.], Microbial enzymes in aquatic environments. Brock/ Springer-Verlag.

Craft, J. A., J. A. Stanford, And M. Pusch. 2002. Microbial respiration within a floodplain aquifer of a large gravel-bed river. Freshw. Biol. 47: 251-261.

DeshPANDE, V., AND K.-E. ERIKSSON. 1988. 1,4- $\beta$-Glucosidases of Sporotrichum pulverulentum, p. 415-424. In W. A. Wood and S. T. Kellog [eds.], Methods in enzymology, v. 160, ParA cellulose and hemicellulose. Academic.

Dubois, M., K. A. Giles, J. K. Hamilton, P. A. Rebers, and F. SмIтH. 1956. Colorimetric method for the determination of sugars and related substances. Anal. Chem. 28: 350-356.

Francoeur, S. N. 2001. Meta-analysis of lotic nutrient amendment experiments: Detecting and quantifying subtle responses. J. North Am. Benthol. Soc. 20: 358-368.

- AND R. G. WETZEL. 2003. Regulation of periphytic leucineaminopeptidase activity. Aquat. Microb. Ecol. 31: 249-258.

FreEman, C., AND M. A. Lock. 1995. The biofilm polysaccharide matrix: A buffer against changing organic substrate supply? Limnol. Oceanogr. 40: 273-278.

HILL, W. 1996. Effects of light, p. 121-148. In R. J. Stevenson, M. L. Bothwell, and R. L. Lowe [eds.], Algal ecology, freshwater benthic ecosystems. Academic.

Hillebrand, H., AND M. KaHLERT. 2001. Effect of grazing and nutrient supply on periphyton biomass and nutrient stoichiometry in habitats of different productivity. Limnol. Oceanogr. 46: $1881-1898$

- , A. L. Haglund, U. G. Berninger, S. Nagel, AND S. WiCKHAM. 2002. Control of microbenthic communities by grazing and nutrient supply. Ecology 83: 2205-2219.

JEFFrEY, S. W., AND G. F. HuMPHREY. 1975. New spectrophotometric equations for determining chlorophylls $a, b$, and $c$ in higher plants, algae and natural phytoplankton. Biochem. Physiol. Pflanz. (BPP) 167: 191-194.

KARNer, M., AND F. RASSOUlzadegan. 1995. Extra-cellular enzyme activity: Indications for high short-term variability in a coastal marine ecosystem. Microb. Ecol. 30: 143-156.

Lawrence, J. R., D. R. Korber, G. M. WolfaArdt, and D. E. CALDWELL. 1995. Surface colonization strategies of biofilmforming bacteria. Adv. Microb. Ecol. 14: 1-75.

Lock, M. A. 1993. Attached microbial communities in rivers, p. 113-138. In T. E. Ford [ed.], Aquatic microbiology: An ecological approach. Blackwell Scientific.

Meyer, J. L. 1994. The microbial loop in flowing waters. Microb. Ecol. 28: 195-199.

Miller, A. R., R. L. Lowe, And J. T. RotenberRy. 1987. Succes- sion of diatom communities on sand grains. J. Ecol. 75: 693709.

Mulholland, P. J., A. D. Steinman, A. V. Palumbo, and J. W. ELWOOD. 1991. Role of nutrient cycling and herbivory in regulating periphyton communities in laboratory streams. Ecology 72: 966-982.

OLFF, H. 1992. Interaction of light and nutrients on growth and allocation in successional grassland species: Separation of level and ratio effects. Oecologia 89: 412-421.

Perrin, C. J., M. L. Bothwell, and P. A. Slaney. 1987. Experimental enrichment of a coastal stream in British Columbia: Effects of organic and inorganic additions on autotrophic periphyton production. Can. J. Fish. Aquat. Sci. 44: 1247-1256.

Peterson, B. J., L. Deegan, J. Helfrich, J. E. Hobbie, M. HulLAR, AND B. MOLLER. 1993. Biological responses of a tundra river to fertilization. Ecology 74: 653-672.

Rier, S. T., AND R. J. STEVENSON. 2002. Effects of light, dissolved organic carbon, and inorganic nutrients on the relationship between algae and heterotrophic bacteria in stream periphyton. Hydrobiologia 489: 179-184.

Roberts, S., S. Sabater, AND J. Beardall. In press. Benthic microalgal colonization in streams of differing riparian cover and light availability. J. Phycol.

RoMANí, A. M., AND J. MARXSEN. 2002. Extracellular enzymatic activities in epilithic biofilms of the Breitenbach: Microhabitat differences. Arch. Hydrobiol. 155: 541-555.

- AND S. SABATER. 2000. Influence of algal biomass on extracellular enzyme activity in river biofilms. Microb. Ecol. 41: $16-24$.

- . AND 2001. Structure and activity of rock and sand biofilms in a Mediterranean stream. Ecology 82: 3232-3245.

Sala, M. M., M. Karner, L. Arin, ANd C. Marrasé. 2001. Measurement of ectoenzyme activities as an indication of inorganic nutrient imbalance in microbial communities. Aquat. Microb. Ecol. 23: 301-311.

Servais, P., A. Anzil, And C. Ventresque. 1989. Simple method for determination of biodegradable dissolved organic carbon in water. Appl. Environ. Microbiol. 55: 2732-2734.

SoBCZAK, W. V. 1996. Epilithic bacterial responses to variations in algal biomass and labile dissolved organic carbon during biofilm colonization. J. North Am. Benthol. Soc. 15: 143-154.

SOKAL, R. R., AND F. J. RoHLF. 1995. Biometry: The principles and practice of statistics in biological research, 3rd ed. W. H. Freeman.

Stelzer, R. S., And G. A. LAmberti. 2002. Ecological stoichiometry in running waters: Periphyton chemical composition and snail growth. Ecology 83: 1039-1051.

Sterner, R. W., J. J. Elser, E. J. Fee, S. J. Guilford, and T. H. ChrZANOWSKI. 1997. The light: nutrient ratio in lakes: The balance of energy and materials affects ecosystem structure and process. Am. Nat. 150: 663-684.

StOcK, M., AND A. K. WARD. 1989. Establishment of a bedrock epilithic community in a small stream: Microbial (algal and bacterial) metabolism and physical structure. Can. J. Fish. Aquat. Sci. 46: 1874-1883.

Wetzel, R. G. 1993. Microcommunities and microgradients: Linking nutrient regeneration, microbial mutualism, and high sustained aquatic primary production. Neth. J. Aquat. Ecol. 27: 3-9.

Received: 9 December 2003 Accepted: 27 April 2004 Amended: 14 May 2004 